University of Wollongong

Research Online

Faculty of Law, Humanities and the Arts Papers (Archive)

$1-1-2020$

Integrating fisheries, food and nutrition - Insights from people and policies in Timor-Leste

Anna K. Farmery

University of Wollongong, afarmery@uow.edu.au

Lana Kajlich

University of Wollongong

Michelle A. Voyer

University of Wollongong, mvoyer@uow.edu.au

Jessica Bogard

Augustinha Duarte

Follow this and additional works at: https://ro.uow.edu.au/lhapapers

Part of the Arts and Humanities Commons, and the Law Commons

Research Online is the open access institutional repository for the University of Wollongong. For further information contact the UOW Library: research-pubs@uow.edu.au 


\title{
Integrating fisheries, food and nutrition - Insights from people and policies in Timor-Leste
}

\begin{abstract}
2020 Elsevier Ltd The important role of fish in food and nutrition security is becoming more widely acknowledged by the fishery sector and within food policy. Integration of fish and food policy, at national, regional or global levels, is required to ensure the contribution of fisheries and aquaculture to human health is supported through governance arrangements. We explore this aspect of food policy integration in Timor-Leste, where malnutrition is a critical health problem. Consumption of fish is low by international standards and only a small proportion of the population engages in fishing. We used a mixed method approach involving desktop policy analysis, interviews and social network analysis to explore interactions among sectoral instruments and organisations. Our results show generally good integration of food security into fisheries policies, but a lack of integration of fish into food policies. Policy network analysis revealed evidence of collaboration and cooperation between sectors, however, consideration of fish and food concerns was not well embedded across all organisations. We discuss challenges and options for future integration of fisheries into sustainable food systems in Timor-Leste and more broadly, including the need for greater political will and resources, combined with clearer targets and actions within instruments.

\section{Disciplines}

Arts and Humanities | Law

\section{Publication Details}

A. Farmery, L. Kajlich, M. Voyer, J. Bogard \& A. Duarte, 'Integrating fisheries, food and nutrition - Insights from people and policies in Timor-Leste' (2020) Food Policy
\end{abstract}




\section{Integrating fisheries, food and nutrition - insights from people}

\section{2 and policies in Timor-Leste}

3 Anna K Farmery*1, Lana Kajlich ${ }^{1}$, Michelle Voyer ${ }^{1}$, Jessica R Bogard ${ }^{2}$, Augustinha Duarte ${ }^{3}$,

$4{ }^{1}$ University of Wollongong, Australian National Centre for Ocean Resources and Security, Wollongong,

5 2522, Australia, afarmery@uow.edu.au

$6 \quad{ }^{2}$ CSIRO, Agriculture and Food, Brisbane, 4067, Australia

$7 \quad{ }^{3}$ WorldFish Timor-Leste, Dili, Timor-Leste

8

\section{Acknowledgements}

The authors would like to acknowledge all interviewees for their time and engagement, and $\mathrm{Mr}$ Mario Cabral for facilitating introductions and providing contact details. We would also like to acknowledge the assistance of Inacia Clart with interviews and translations, and Prof Neil Andrew and anonymous reviewers for their comments.

\section{Abstract}

The important role of fish in food and nutrition security is becoming more widely acknowledged by the fishery sector and within food policy. Integration of fish and food policy, at national, regional or global levels, is required to ensure the contribution of fisheries and aquaculture to human health is supported through governance arrangements. We explore this aspect of food policy integration in Timor-Leste, where malnutrition is a critical health problem. Consumption of fish is low by international standards and only a small proportion of the population engages in fishing. We used a mixed method approach involving desktop policy analysis, interviews and social network analysis to explore interactions among sectoral 
instruments and organisations. Our results show generally good integration of food security into fisheries policies, but a lack of integration of fish into food policies. Policy network analysis revealed evidence of collaboration and cooperation between sectors, however, consideration of fish and food concerns was not well embedded across all organisations. We discuss challenges and options for future integration of fisheries into sustainable food systems in Timor-Leste and more broadly, including the need for greater political will and resources, combined with clearer targets and actions within instruments.

\section{Key words}

Policy integration, food security, seafood, aquaculture, food systems, fisheries management

\section{Introduction}

More integrated food policy is needed to overcome problems facing the food system, including food insecurity, malnutrition, non-communicable diseases (NCDs) and environmental degradation (see for e.g. Barling et al., 2002; Candel and Pereira, 2017). Fisheries and aquaculture make important contributions to national food systems (Béné et al., 2016; Bogard et al., 2019; Kawarazuka and Béné, 2011; Loring et al., 2019; McClanahan et al., 2013; Thilsted et al., 2016), however, this role was all but ignored until recently (Béné et al., 2015; Farmery et al., 2017; HLPE, 2014; Kurien and López Ríos, 2013). Fisheries and aquaculture have typically been considered separately from other parts of food and agricultural systems in food and nutrition security (FNS) research and policy-making (Kawarazuka and Béné, 2011). The contribution of fish (including all marine and fresh water farmed and capture species) to food systems has been limited by a lack of coordination across the respective policy domains (FAO, 2017). 
The call for closer integration of fish into the FNS debate (Béné et al., 2015) has resonated with researchers and policy makers alike. The literature on the role of fisheries and aquaculture in FNS has increased dramatically in recent years (Bennett et al., 2018) and the international community has highlighted the need to integrate fish into local and national food systems, to establish nutrition-sensitive fisheries and to improve future diets (FAO, 2017; Thilsted et al., 2016). The need for capture fisheries and aquaculture to be addressed comprehensively through coordinated public policies (Chan et al., 2019; FAO/WHO, 2014) to improve FNS has also been promoted.

Recent efforts to improve the integration of fisheries and food policy include the development of voluntary guidelines to support the role of small-scale fisheries in efforts to eradicate hunger and poverty (FAO, 2015). The Asia-Pacific Fishery Commission (APFIC) have promoted better communication around fish for FNS in policy decision-making, and increased efforts to provide information on fish, and fish consumption, at national and sub-national levels (Needham and Funge-Smith, 2014). In East Asia, a number of regional ocean programs and partnerships have identified the need to manage fisheries for FNS, including the Resolution and Plan of Action on Sustainable Fisheries for Food Security for the ten countries in the Association of Southeast Asian Nations (ASEAN) Region.

64 The Coral Triangle Initiative on Coral Reefs, Fisheries and Food Security (CTI-CFF), a multilateral partnership formed by the governments of the six Coral Triangle countries has also identified the need to manage fisheries for FNS. The success of these programs in 
integrating fish and FNS is uncertain, however, as they have been limited by the lack of clear targets on improving access or consumption of fish (Foale et al., 2013).

Despite increased focus, the way in which fisheries, aquaculture, food and health are being integrated, at national, regional or global levels, and the implications for both fisheries management and food and health outcomes, remains an under-researched area. We begin to explore this emerging aspect of food policy integration through an examination of policy instruments and actors in Timor-Leste where malnutrition is a critical health problem and existing policy has not captured the potential contribution of fish to food systems (Mills et al., 2017). Our approach is applicable to other countries, where the integration of fish and food policy can support the range of actions required to overcome malnutrition and food insecurity.

\subsection{Case study - Timor-Leste}

Timor-Leste is a small Southeast Asian nation with a population of approximately 1.3 million people. It is a post-conflict country emerging from a history of occupation, a violent struggle for independence, and internal conflicts between 1999 and 2006 (Provo et al., 2016). TimorLeste occupies half of the island of Timor and is predominantly agricultural. Food insecurity is a major problem resulting from past conflicts, environmental degradation, disrupted land tenure and farm practices, severe seasonal weather fluctuations, and dependence on food imports (Anderson, 2006). Most families suffer from chronic food insecurity and practice food rationing between one and six months of the year (Borges et al., 2009). Timor-Leste was 
ranked 110 out of 119 countries included in the 2018 Global Hunger Index, and is one of only two where more than $50 \%$ of children under five are stunted (von Grebmer et al., 2018). The overall nutrition situation of the country is poor with $38 \%$ of children under five years of age underweight and $11 \%$ wasting. In addition, micronutrient deficiencies exist among children and non-pregnant mothers, especially anaemia (Democratic Republic of Timor-Leste, 2015). FNS is addressed through a number of national policies and plans, as well as regional instruments. For example, Timor-Leste is a member of the Community of Portuguese Language Communities (CPLP) which has developed the ESAN-CPLP Regional Strategy for Food and Nutrition Security 2011. The country is an observer to the regional intergovernmental organisation ASEAN, who have developed an Integrated Food Security Framework and Strategic Plan of Action on Food Security in the ASEAN Region (SPA-FS) 20152020.

Fish is a highly nutritious food and its consumption has been linked to reduced rates of malnutrition (Golden et al., 2016). Average fish consumption in Timor-Leste is estimated to be $6.1 \mathrm{~kg} /$ person/year (17 kg in coastal areas and $4 \mathrm{~kg}$ in inland communities), which is less than the current global average of $20.3 \mathrm{~kg}$ (FAO, 2018). Increasing the consumption of fish may, therefore, be part of the solution to help improve the country's nutrition situation. The Timorese Government has supported the role of fish in its populations' diet through initiatives such as the Food Based Dietary Guidelines (Government of Timor Leste, 2015).

Fish landings, which peaked in the 1990s during Indonesian occupation, declined after 1999 following post-referendum conflicts in which Indonesian militias destroyed approximately $90 \%$ of boats, fishing gear and onshore processing infrastructure (Barbosa and Booth, 2009). In contrast to many other nations, the Timor-Leste wild capture fisheries sector is currently 
considered to be 'undeveloped', although there are indications of localised overfishing (Alonso Población, 2013). The sector is dominated by small-scale fisheries (SSF) with approximately $5 \%$ of total households involved in SSF to some degree (López-Angarita et al., 2019). Inland capture fisheries are largely limited to the monsoon season and predominantly carried out for subsistence (FAO, 2019). The number of households involved in aquaculture was estimated at around 3500 (1.75\% of total households) in 2016 (WorldFish, 2019). Fishery resources are managed through a mix of co-management and customary laws and national regulations (Alonso-Población et al., 2018; Tilley et al., 2019). Several marine protected areas environmental non-government organisations and community groups. Timor-Leste is a Initiative on Coral Reefs, Fisheries and Food Security (CTI-CFF). Combating Illegal, Unreported and Unregulated Fishing in the Region, and the Coral Triangle (MPAs) have also been established with varied levels of engagement from government, signatory to the Regional Plan of Action to Promote Responsible Fishing Practices including The majority of capture fisheries production, estimated to be around $3200 \mathrm{t}$, is consumed domestically. Freshwater aquaculture production is estimated at over $350 t$, and $15 \mathrm{t}$ of seaweed were produced for export, with a greater volume reportedly produced for the local market (WorldFish, 2019). Fresh fish is most commonly purchased from fishers or at market and some households also purchase imported canned or frozen fish (AMSAT International, 2011). The topography of the country makes transport of fresh fish difficult. Lack of processing and landing infrastructure also limits fish marketing and trade. The domestic market for fish remains underdeveloped and for many upland communities in the country's interior, fish is rarely consumed (FAO, 2019). 


\section{Methods}

Food insecurity is a trans-disciplinary, multi-sectoral policy field requiring an integrated policy approach (Barling et al., 2002; Candel and Pereira, 2017). Policy integration, where certain policy objectives are integrated into other policy sectors (Mickwitz and Kivimaa, 2007), is required alongside actions at multiple levels and across different sectors to overcome the range of factors that lead to malnutrition and chronic conditions such as stunting (Bhutta et al., 2013).

We examine policy coordination and cooperation between the fisheries and food sectors as components of policy integration, which is understood here as a process of both policy and institutional change and design (Candel and Biesbroek, 2016). Integrated policy often requires self-standing policy networks, or subsystems to be integrated (Meijers and Stead, 2004). These networks can be defined as patterns of social relationships between independent actors which take shape around policy problems or programs (Kickert et al., 1997). We used a mixed methods approach, building on methods recently described in the literature on policy coherence (Cohen et al., 2017; Nilsson et al., 2012), processual policy integration (Candel and Biesbroek, 2016, 2018), and social network analysis (SNA) (Freeman, 2004; Wasserman and Faust, 1994). Research was conducted during 2018 and 2019 through desk-based analysis of relevant instruments (legislation, polices, strategies or plans), followed by stakeholder interviews. 
Firstly, we examined the key instruments in the sectors of fisheries, aquaculture, food, nutrition and health. A total of 20 relevant documents were identified via internet keyword searches, references to policy instruments within identified instruments, conversations with academics and staff of the Ministry of Agriculture and Fisheries, and through targeted questions in formal interviews with stakeholders (see supplementary information Table S1). Instruments included in the analysis were limited to regional and national documents containing stated goals or objectives relating to food, nutrition, and health or fisheries and aquaculture. This approach resulted in the inclusion of several multi-sectoral instruments that lie outside the fish and food sectors, for example the Environment Basic Law 2012 and the National Biodiversity Strategy and Action Plan 2011-2020, as they included specific objectives on fisheries or FNS. Instruments such as the National Disaster Risk Management Policy 2008 which mentions that food insecurity must be addressed, or the National Tourism Policy 2015 that mentions food in relation to tourist needs, were not included. Key development partner strategies were examined but not included in the analysis as they were not formal government instruments. A summary of the inclusion of fish and FNS objectives in these documents is available in the supplementary material (see Table S2).

Secondly, we examined the stated objectives within the selected instruments, including national policies, plans, strategies, legislation, and relevant regional strategies and plans. This analysis was undertaken to assess the extent of integration of FNS considerations into national and regional fisheries, ocean and aquaculture instruments (referred to as the fisheries, ocean and aquaculture sector); and how fish considerations are included in national and regional FNS instruments (referred to as the food, nutrition and health sector). An 
inventory of all relevant stated objectives was developed following the approach used by Nilsson et al. (2012). This process resulted in the identification of a large number of objectives, which were sorted into groups or 'themes', where commonalities between specific objectives existed. These themes were used to report results. Nutritional intake and food security were separated in the analysis to capture the extent to which policies addressing food security also considered nutrition, given the historical focus of food security on food quantity rather than quality, and the particular role that fish can play in addressing malnutrition.

A number of 'shared' objectives were identified, i.e., the same theme was present in one or more sectors. We considered such shared objectives as critical to the process of reconciling different policy instruments and to achieving full policy integration (Candel, 2018). Shared objective themes were further examined to understand the level of coherence, or 'mutual consistency', between different sectors. The objectives that were not shared among sectors, i.e., they were articulated in the instruments of a single sector only, or were poorly represented within and across sectors, were examined as potential obstacles or opportunities for integration. The level of integration or commitment, based on whether or not the objective was linked to a clear strategic action or target which it can be measured against, or identification of who was responsible for implementation, was noted during this stage.

\subsection{Stakeholder interviews}

Stakeholders from government, academia, intergovernmental organisations and NGOs actively engaged in management, policy development and implementation relevant to 
fisheries, oceans, aquaculture, and food, nutrition and health were interviewed to provide insight into the sector networks and how, or where, these food policy subsystems interconnect. Interviewees were identified through mention of their name or organisation in the desk-based policy analysis, and via the snowball approach through conversations and formal interviews. A small number of interviewees were identified from additional subsystems, including environment and agriculture, and our analysis captures a fraction of the objectives of these sectors, as they relate to fisheries and food, rather than the full spectrum of sectoral objectives. A total of 31 structured interviews were conducted to explore the objectives interviewees were trying to achieve in their professional capacities, the instruments they used, and the networks that exist with other professionals and organisations. Interviews were also used to identify new members of the network and were conducted with as many members as was possible. Interviews, conducted face-to-face or over Skype, were carried out in English or Timorese, with assistance from a translator to ensure accuracy and detail of nuanced discussions. Two interviewees completed interview questions via return email where a conversation was not possible. Results were de-identified and analysed using thematic analysis and SNA software.

\subsection{Social Network Analysis}

Social network analysis was used to provide an indication of the strength of relationships between organisations that cannot be captured through analysis of policy documents on their own. The aim of the network analysis was to examine the food policy subsystems and identify the policy network linking the fisheries, ocean and aquaculture sector and the food, nutrition and health sector. Interviewees were asked to name the organisations that were important for their work as well as the instruments they used. The results of individual interviews were 
aggregated, analysed and graphed to show these interactions. Open source software (Gephi

227

0.9.2; Force Atlas 2 Projection) was used to measure relative distance, or relationships, between organisations and between instruments. For the relationships between organisations we present results for betweenness centrality, based on the centrality of organisations in providing links, or 'bridges' between organisations. For the relationship between organisations and instruments we present results on the indegree or 'popularity', which is a measure of centrality based on the number of references to an instrument.

To analyse the results, we assigned organisations (based on interviewee organisation) and instruments to sectors. Organisations were assigned based on the main focus of the interviewees. For example the Ministry of Agriculture and Fisheries and several tertiary institutions were assigned to 'fisheries, oceans and aquaculture', as all interviewees from these organisations identified primarily with this sector, despite their organisation representing multiple sectors. We note the difficulty in determining boundaries to allocate people and organisations to sectors and recognise that they are analytical constructs to help interpret results rather than firm demarcations (Nohrstedt and Weible, 2010). In some cases more than one person was interviewed, or completed the survey, per organisation (see Tables S3 and S4). In other cases interviewees were not available for organisations identified as part of the network. Given these limitations, some links between organisations or instruments may not be represented in the results, and the bridging role of some organisations may be under-represented (betweenness value). Our results should, therefore, be interpreted in terms of general patterns presented in the results section, rather than the exact values (see Tables S3-5 for indegree, betweenness and eigenvector centrality values). 


\subsection{Integration of fish and food within sectoral instruments}

252 Instruments (legislation, policies, strategies or plans) were categorised into the following sectors: food, nutrition and health; fisheries, oceans and aquaculture; strategic development; and environment. Fisheries, ocean and aquaculture-specific objectives were articulated by a third of instruments categorised in the food, nutrition and health sector (Table 1, and see Table S6 for detail of specific instruments) demonstrating a degree of policy integration. For example, the National Food and Nutrition Security Policy 2017 includes an objective to increase fish consumption from $6 \mathrm{~kg}$ to $15 \mathrm{~kg}$ per capita. However, some key instruments had no objectives related to fish (for e.g. the National Nutrition Strategy 2014-2019) illustrating a clear lack of integration. Within the fisheries, ocean and aquaculture sector, there was a high level of integration with $80 \%$ of instruments including FNS objectives. For example, the National Aquaculture Development Strategy 2012-2030 also included an objective to increase annual fish consumption to $15 \mathrm{~kg}$ per capita.

Table 1 Policy integration as a function of presence of objectives across sectors

\begin{tabular}{|l|l|l|}
\hline & \multicolumn{2}{|l|}{ Instruments with objectives addressing: } \\
\hline Sector & Food and nutrition security & Fish, fisheries or aquaculture \\
\hline Food, nutrition and health & $100 \%(n=6)$ & $33 \%(n=2)$ \\
\hline Fisheries, aquaculture and oceans & $80 \%(n=8)$ & $100 \%(n=10)$ \\
\hline
\end{tabular}


While many instruments demonstrated a degree of integration in terms of expressed commitment or acknowledgement of issues related to fisheries and to FNS, many instruments contained broad objectives that did not include clear strategic actions or targets to be measured against, an indication of how or by who the commitment would be implemented

270 (Table S1). For example, the National Food and Nutrition Security Policy 2017 does not detail how fish consumption would increase to meet the target of $15 \mathrm{~kg}$ per year. Some objectives constituted vague statements only, for example the Decree-Law No. 6/2004, the General Bases of the Legal Regime for the Management and Regulation of Fisheries and Aquaculture,

274 acknowledged the importance of fishing "in improving the food diet of the populations", with no further information.

277 A range of shared objective themes were identified in the food, nutrition and health instruments, and the fisheries, oceans and aquaculture sector instruments (Table S1 lists all shared objective themes for all instruments and sectors). The most common food, nutrition and health objective themes, i.e., the themes that were stated in the most instruments for that sector, included 'improved public health', 'food security', 'nutritional intake', 'education, awareness and advocacy on food and nutrition', and 'effective governance' (Figure 1). These objective themes appeared in over $80 \%$ of instruments in the food, nutrition and health sector. 


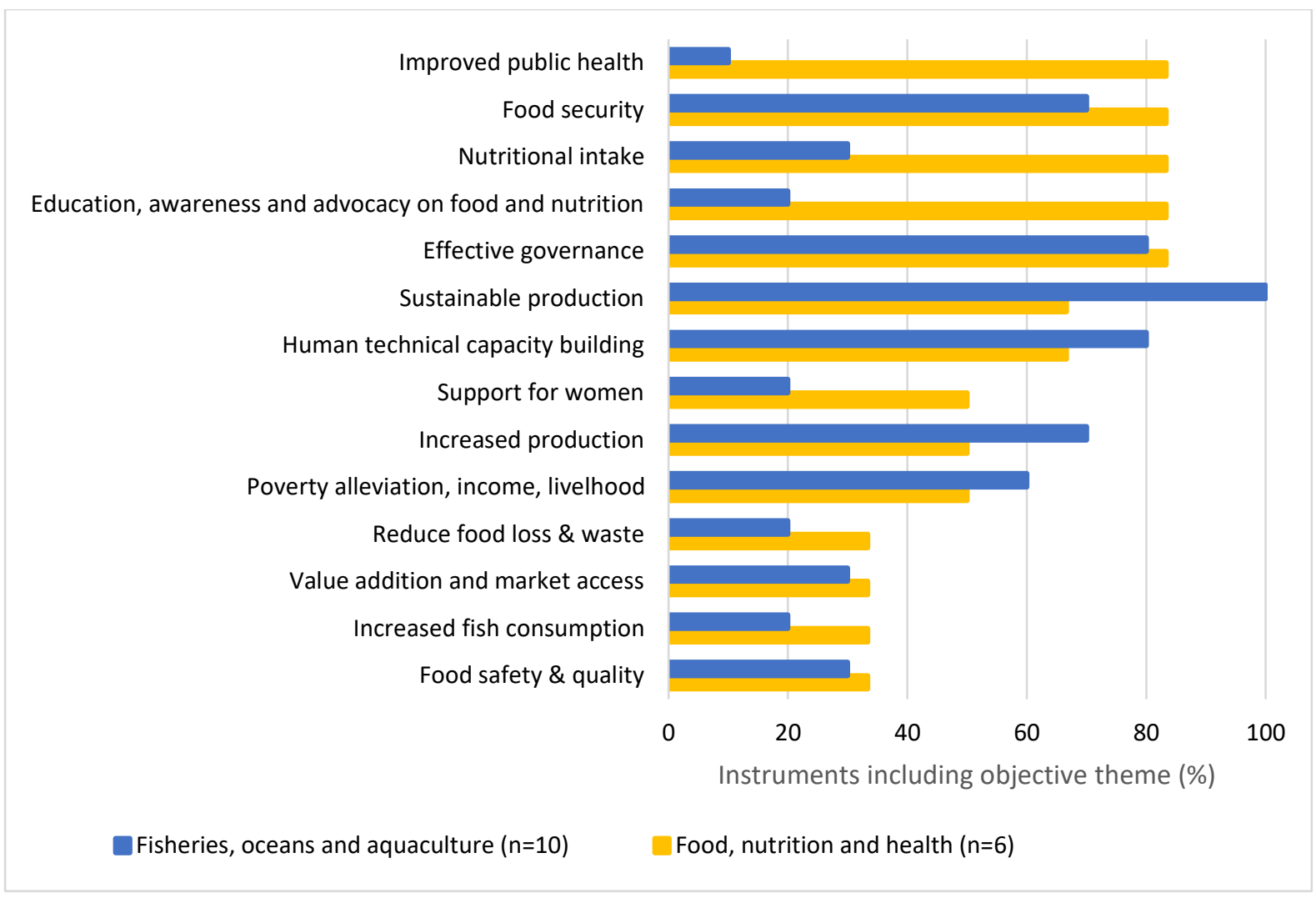

Figure 1 Sectoral coverage of the most common food, nutrition and health objective themes, i.e., the themes that were stated in the most instruments for that sector present in $67 \%$ of food, nutrition and health instruments and these commonly articulated objective themes were well represented in the strategic plans. Some of the objectives around sustainable production were quite broad. For example, the objective "Enhance capacities of rural communities, land owners and farmers to use natural resources in a sustainable manner to support an adequate and stable supply of locally produced nutritious food" in the Food and Nutrition Security Policy 2017, was not accompanied by implementation actions or targets. Some of these themes were also frequently articulated, or shared, in fisheries, oceans and 
aquaculture instruments, including 'sustainable production' (100\%), 'effective governance' 'human technical capacity building' (80\%), and 'food security' (70\%).

The most common objective themes for fishery, oceans and aquaculture related to 'sustainable production' (100\%), 'effective governance' and 'human technical capacity building' (80\%), 'food security' and 'increasing production' (70\%), 'reducing poverty' and 'compliance and enforcement of regulations' (60\%) (Fig 1 and Fig S1).

\subsubsection{Under-represented themes in instruments}

Several common food and health themes were under-represented in fisheries instruments, for example 'improved public health' (10\%) 'education, awareness and advocacy on food and nutrition' (20\%), and 'nutritional intake' (30\%) (Figure 1). Some common fisheries objective themes, including 'conservation' (70\%) and 'creating new economic opportunities/ livelihood diversification' (50\%) were not articulated in any FNS instruments (Table 2, Figure S1), while others such as (compliance and enforcement of national and international regulations', 'small-scale and traditional fisher/farmer support' and 'industry/sector development' were articulated in a third or less of food, nutrition and health sector instruments (Figure S1).

A number of objective themes were shared across sectors yet remained under-represented (33\% or less) in one or both sectors, including 'support for women', 'reduced food waste and loss', 'value addition and market access', 'increased fish consumption', 'small-scale fishers and farmers', 'industry development' and 'food safety and quality'. Some of these themes were also shared by the strategic development and agriculture sector instruments included in this analysis (Table S1, S7), although this is not reflective of these sectors as a whole. oceans and aquaculture instruments and also under-represented in food, nutrition and health 
instruments. These included 'food price stability and affordability', 'improving nutritional

321 behaviour' and 'food self-sufficiency' (Table 2). Several FNS objectives, including 'education and awareness on food and nutrition', 'improving the nutritional value of food' and 'human rights', were included in ASEAN instruments but remained gaps in national instruments.

Shared objectives were expected across instruments that focus on both fisheries and food security, such as the ASEAN Resolution and Plan of Action on Sustainable Fisheries and Food

Security, and the regional and national plans of the Coral Triangle Initiative on Fisheries and

Food Security (CTI), however, these documents demonstrated gaps in relation to key food and nutrition objectives. For example, neither CTI instrument contained objectives related to 'increased production of food', 'nutritional intake', 'food safety/quality', or 'increased food consumption'.

Table 2 Thematic areas where objectives were absent or under-represented across sectors.

The values indicate the percentage of instruments, in a sectoral group, and the total number,

\begin{tabular}{|c|c|c|c|c|c|c|c|c|c|c|c|c|c|c|}
\hline & \multicolumn{6}{|c|}{ FNS objective themes } & \multicolumn{8}{|c|}{ Fish objective themes } \\
\hline Sector & 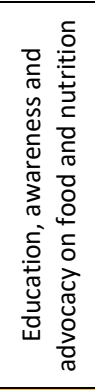 & 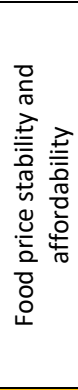 & 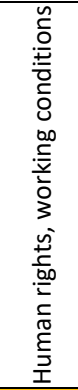 & 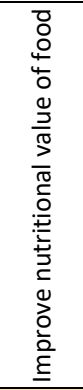 & 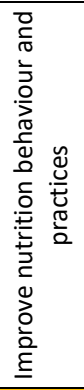 & 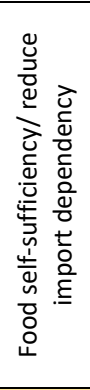 & 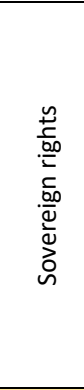 & 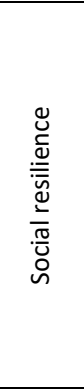 & 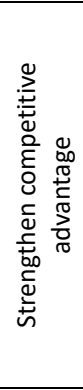 & 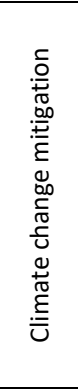 & 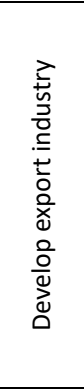 & 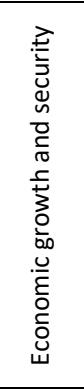 & 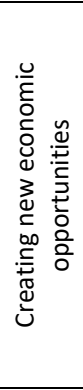 & 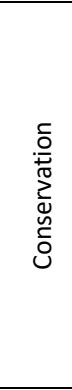 \\
\hline $\begin{array}{l}\text { Food, } \\
\text { nutrition } \\
\text { \& health }\end{array}$ & $\begin{array}{l}83 \% \\
(n=5)\end{array}$ & $\begin{array}{c}67 \% \\
(n=4)\end{array}$ & $\begin{array}{c}50 \% \\
(n=3)\end{array}$ & $\begin{array}{c}33 \% \\
(n=2)\end{array}$ & $\begin{array}{c}50 \% \\
(n=3)\end{array}$ & $\begin{array}{c}33 \% \\
(n=2)\end{array}$ & $\begin{array}{c}17 \% \\
(n=1)\end{array}$ & & & & & & & \\
\hline $\begin{array}{l}\text { Fisheries, } \\
\text { oceans \& } \\
\text { aquacul- } \\
\text { ture }\end{array}$ & $\begin{array}{c}10 \% \\
(n=1)\end{array}$ & & $\begin{array}{c}10 \% \\
(n=1)\end{array}$ & $\begin{array}{c}10 \% \\
(n=1)\end{array}$ & & & $\begin{array}{c}10 \% \\
(n=1)\end{array}$ & $\begin{array}{c}10 \% \\
(n=1)\end{array}$ & $\begin{array}{l}10 \% \\
(n=1)\end{array}$ & $\begin{array}{c}20 \% \\
(n=2)\end{array}$ & $\begin{array}{c}10 \% \\
(n=1)\end{array}$ & $\begin{array}{c}30 \% \\
(n=3)\end{array}$ & $\begin{array}{c}50 \% \\
(n=5)\end{array}$ & $\begin{array}{c}70 \% \\
(n=7)\end{array}$ \\
\hline
\end{tabular}




\subsection{Integration through networks}

338 Interviewees and their organisations were categorised into fisheries, oceans and aquaculture; food, nutrition and health; and agriculture sectors. More than $63 \%$ of interviewees $(n=12)$ in the 'fisheries, oceans and aquaculture' sector listed food security as an additional primary or secondary work sector. In contrast, only one of eight interviewees in the food, nutrition and health sector identified fisheries or aquaculture as an additional sector. Half of the interviewees in the agriculture sector $(n=2)$ listed fisheries or aquaculture as a secondary sector.

The objective theme most commonly reported by interviewees in the food, nutrition and health sector related to 'nutritional intake' (63\%). For example, interviewees reported objectives such as "contribute to nutrition intake for households". Objectives linked to this theme were reported by one interviewee in fisheries, aquaculture and oceans sector. Several other objective themes reported by two or more interviewees in the food, nutrition and health sector $(\geq 25 \%)$ were also reported by interviewees working in fisheries, oceans and aquaculture (Figure 2, also see Table S8 for more detail). These shared objectives included 'Human technical capacity building' (reported by $39 \%$ fisheries, oceans and aquaculture sector, $25 \%$ food, nutrition and health sector), for example "capacity development through training students in communities", 'food security' (17\%, 25\%), and 'support for government' (11\%, 25\%). Shared objectives also included 'Effective governance' $(6 \%, 25 \%)$ and 'Poverty, 
alleviation, income and livelihoods' (11\%, 13\%), for example "contribute to household income". reported by any interviewees from the fisheries, oceans and aquaculture sector, including 'education, awareness and advocacy on food and nutrition' (25\%), 'youth support' (25\%), and 'improved public health' (25\%). Objectives related to 'support for women' were reported by $25 \%$ of food, nutrition and health sector interviewees and $50 \%$ of agriculture sector interviewees (Table S8, noting that this does not reflect the sector as whole given the limited number of interviewees), but not by any fisheries, ocean and aquaculture interviewees.

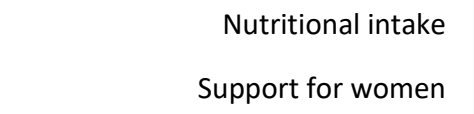

Human technical capacity building Food security

Effective governance Support government, policy development $\&$ review Education, awareness, advocacy on food \& nutrition Youth support
Improved public health
Poverty alleviation, income, livelhood Youth support
Improved public health
Poverty alleviation, income, livelhood Youth support
Improved public health
Poverty alleviation, income, livelhood

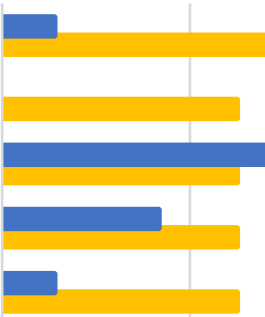

$\sqrt{2}$

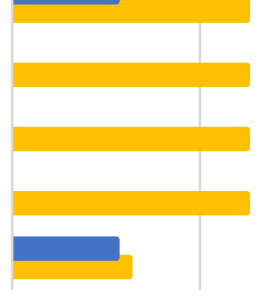

0 20 40 60 80 Interviewees reporting objective theme (\%)

Fisheries, oceans and aquaculture $(n=18) \quad$ Food, nutrition and health $(n=8)$ themes. 
Some of the objective themes reported by interviewees in fisheries, oceans and aquaculture were not mentioned as objectives by interviewees in the food, nutrition and health sector. These included 'sustainable production' (reported by $28 \%$ of respondents in the fisheries, ocean and aquaculture sector), 'collection, monitoring and sharing of data' (28\%), 'compliance with and enforcement of national or international regulations' $(22 \%)$ and 'industry innovation/sector development (17\%)' (Table S8, Figure S2).

\subsubsection{Theme trends across instruments and interviews}

The objective themes most commonly shared by sectors, across instruments and interviews, related to capacity building and food security. Several interviewees stated that fisheries were not a political priority in Timor-Leste, with very low budget allocation. Effective governance was reported as an objective by only one fisheries, ocean and aquaculture interviewees, despite being present in $80 \%$ of sector instruments. This may be a result of allocation of coding themes, as 'support for government' was a commonly reported objective by interviewees but was not in instruments, and the two themes may in reality be mutually supportive. Sustainable production and effective governance themes were also commonly present across instruments and interviews, however, sustainable production was not reported by food, nutrition and health sector interviewees, despite being present in $67 \%$ of sector instruments.

A number of objectives that are broadly recognised as important for achieving FNS were under-represented across both the fishery, ocean and aquaculture sector as well as the food, nutrition and health sector. For example, objectives supporting 'increased fish consumption' were present in two of six food, nutrition and health sector instruments, and two of ten 
fishery, ocean and aquaculture sector instruments. A total of two interviewees reported working toward increasing fish consumption, both were from the fishery, ocean and aquaculture sector.

Improving the nutritional value of fish (or food) was identified in only one national instrument, and two regional instruments. None of the interviewees described improving the nutritional value of fish (or food) as an objective. Objectives relating to 'food price stability and affordability' were present in $67 \%$ of food, nutrition and health instruments but were absent from fishery, ocean and aquaculture sector instruments and were not identified through any interviews. 'Food quality and safety' was not identified as an objective theme by any interviewees, although it was an objective theme present in approximately a third of fishery, ocean and aquaculture, and food, nutrition and health sector instruments.

The objective themes that had the lowest representation in instruments and interviews included some important areas such as equity; support for youth; reduced food loss and waste; education, awareness and advocacy on food and nutrition; improve nutrition behaviour and practices; and respecting cultural and traditional values (Table S1 and S5). Education and awareness raising is particularly important in Timor-Leste, as one interviewee stated, given the "poor general knowledge of food security, sovereignty, and nutrition" in the country. A number of the findings from the instrument analysis were supported through interviews. For example, the finding that some instruments contained very broad objectives was articulated through interviews “... the documents are all broad and not followed up on, multisector documents overlap, and the links with sectoral plans are not strong." 


\subsubsection{Organisation and instrument interaction}

420 Many interviewees identified instruments in their own sector, including internal instruments

421 within their own organisation, as most important to their work. One multi-sectoral 422 instrument, the Strategic Development Plan 2011-2030, emerged as a key instrument across sectors (Fig 3). A second key instrument linking the Timor-Leste FNS and fisheries networks was the National Nutritional Strategy 2014-2019. The prominence of this instrument for

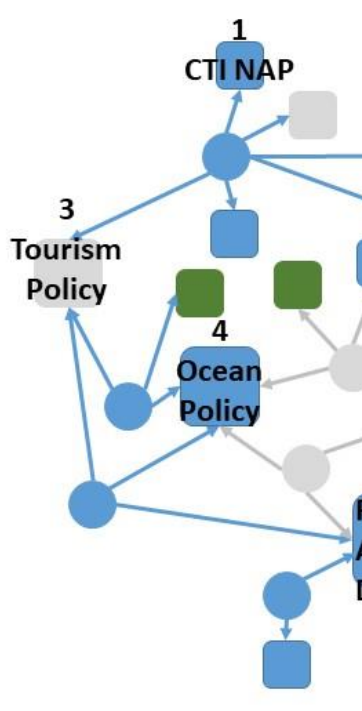

Figure 3 Instruments (squares) used by organisations (circles). The size of the instrument marker is based on in-degree and indicates 'popularity' of usage, or number of mentions. Indegree values displayed for select instruments, all values available in Table S5. Key: Coral Triangle Initiative National Action Plan (CTI NAP), Sustainable Development Goals (SDGs). 
Interviewees were asked to name the organisations of importance for their work. The results highlight the position of one organisation, the Ministry of Agriculture and Fisheries (MAF) as a key linking organisation for collaboration across diverse sectors (Fig. 4). Potential limitations of MAF's role in the network were raised by interviewees who stated the organisation has "... no capacity to go beyond food and nutrition security to systems of delivery." The MAF Strategic Plan 2014-2020 was not identified as a key linking instrument, despite the prominence of the organisation in the network. MAF has a broader mandate than fisheries, oceans and aquaculture, however, it has been categorised in this sector based on the focus of interviewees. The two other key linking organisations were the FAO and the Ministry of Health. The results demonstrate a level of cooperation and collaboration between sectors, although it is clear that full integration has not occurred across all organisations. In addition, some sectoral disconnect was evident, in particular between organisations linked to the environment sector and those most closely linked to the food, nutrition and health sector. This disconnect may not represent a complete lack of interconnectedness, as connections through informal and formal working groups, and links with organisations that are considered less important, are not represented here. The results do indicate that only a small number of organisations outside of each sector were considered 'important' for achieving objectives. These organisations act as bridges to link other organisations that would otherwise be less connected within the network and without these organisations the network would risk lack of connectivity. 

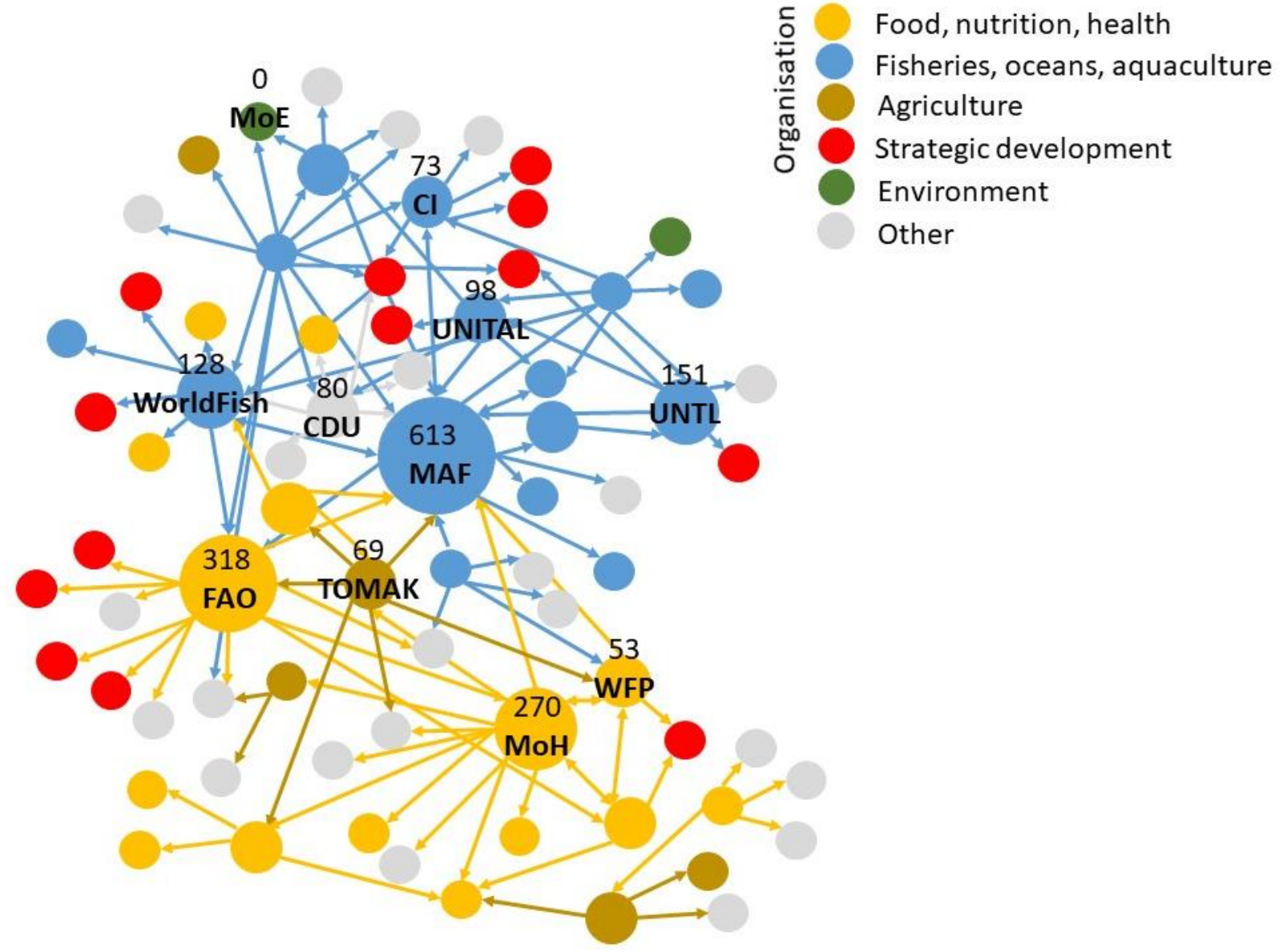

Figure 4 Network of organisations based on between-ness centrality or linkages between organisations. The size of the marker indicates 'popularity', or number of mentions. Examples of values shown for select organisations, all values available in Table S3. Key: Ministry of Environment (MoE), Charles Darwin University (CDU), Ministry of Agriculture and Fisheries (MAF), Universidade Oriental Timor Lorosa'e (UNITAL), Conservation International (CI), National University of TimorLeste (UNTL), Food and Agriculture Organization of the United Nations (FAO), To'os ba Moris Di'ak) program (TOMAK), World Food Program (WFP), Ministry of Health (MoH).

Integration of fisheries in food policy is occurring in Timor-Leste as a result of coordination among both instruments and organisational networks. The integration of FNS concerns appears more widespread in fisheries, oceans and aquaculture instruments and networks 
than the integration of fish by the food, nutrition and health sector. This finding suggests that the role of fish in FNS remains a lower priority for the FNS sector than for fisheries, and that the disconnect in the system may be an effect of the directionality of the network links, rather than the extent of the connections. Policy integration is also constrained by the limited breadth of objectives of instruments and organisations, with several key FNS objectives remaining under-represented across sectors. There is opportunity to build on existing instruments and networks, as well as to coordinate activities between sectors to better integrate fish to achieve FNS outcomes.

\subsection{Indications of integration in instruments, organisations and networks}

Food security was articulated as an objective in the vast majority of instruments, as well as interviews, in the fisheries, oceans and aquaculture sector. While nutritional intake was not as frequently articulated, results indicate the fisheries sector has been proactive in integrating FNS concerns and objectives articulated in policies are being implemented through organisations, or organisations are being supported through policy to implement FNS objectives. In contrast, there was limited integration of fish-related objectives within instruments or interviews in the food, nutrition and health sector, with one key instrument, the National Nutritional Strategy 2014-2019, containing no objective themes related to fish.

The policy network analysis revealed evidence of cooperation and collaboration among sectors on issues of fisheries and food, although they were not well embedded across all organisations. There was also a degree of sectoral disconnect, in particular in relation to 
were identified as being important to the fishery and food policy network may be indicative of a broader disconnect between fisheries and agriculture.

\subsection{Challenges to policy integration}

\subsubsection{Range and depth of objective themes}

Despite the promising level of integration of FNS objectives visible in the fisheries, ocean and aquaculture sector, the extent of integration was limited in terms of both coverage of FNS themes as well as clear paths to achieve stated objectives. The vagueness of some statements relating to FNS in many of the fisheries instruments represents a possible explanation for the mismatch between the seemingly good level of integration and the reality that fish does not currently play a strong role in alleviating hunger and malnutrition in Timor-Leste. For example, clear actions and targets on increasing production and consumption, and on nutrition intake and behaviour were lacking in regional and national instruments. The lack of clarity of many objectives was also evident in some food, nutrition and health sector instruments, in particular in relation to increasing consumption of fish. A loss of specificity of designing actions was also identified in an assessment of integration of fish into food and nutrition policy in East Africa (Kurien and López Ríos, 2013). Identifying clear actions and targets in objectives is an important aspect for integration, particularly within key linking instruments.

Lack of clear targets may result in limited implementation, or worse in incoherent or countervailing objectives. For example, there are potential synergies and trade-offs between marine conservation, resource management, and FNS concerns which need to be considered (HLPE, 2014). Conservation related objectives were not mentioned by interviewees in the food, nutrition and health sector, however, given the predicted growth of Blue Economy 
activities in Timor-Leste, the interactions between fisheries production, conservation and FNS

will need to be clarified and managed across sectors (Quirk et al., in review). Several fisheries, oceans and aquaculture sector organisations that listed tourism and conservation as additional sectors also reported food security as one of their key objectives. Some of these organisations were linked to the CTI National Action Plan. The CTI on Coral Reefs, Fisheries and Food Security (CTI-CFF) has set a target to improve income, livelihoods and food security in coastal communities across the Coral Triangle region in their regional plan of action (Coral Triangle Initiative, 2009). While the CTI has explicit goals and defined targets for marine biodiversity conservation, pathways for achieving FNS outcomes will need to be clarified to help overcome food insecurity in the region. We found that the CTI network was linked to tourism, fisheries and environmental instruments, but not to any FNS instruments or organisations. Establishing these links is important given that MPAs are used globally as a fisheries management and conservation tool, and their design is critical to their success in relation to food security (Cabral et al., 2019). In Timor-Leste, the success of MPAs has not been critically assessed (López-Angarita et al., 2019) and there is a need to ensure legitimate community engagement in fisheries governance to avoid external appropriation and marginalisation of certain user groups or customary power hierarchies (Tilley et al., 2019). benefit proponents of intensifying food production and trade liberalisation more than those who are food insecure (Jarosz, 2011; Rosin, 2013; Tomlinson, 2013). Clear pathways are required for objectives on increasing fish production, and on developing the export industry

537 in developing countries, to ensure their contribution to overcoming food and nutrition 538 insecurity and meeting sustainable development goals. Sustainable production and use was 
a common objective for instruments across sectors, and for fishery, ocean and aquaculture organisation, however, it was not reported by any interviewees in FNS. This may be a function

541 of a lack of detail on implementation in instruments. Objectives for sustainable production will need to be closely linked to objectives to increase the production of fish, which was a

543 focus across sectors. Weak links between environmental sustainability of fisheries and food security has been identified as an impediment to securing sustainability in fisheries (Hall et al., 2013).

The lack of clear pathways for implementation is compounded in Timor-Leste by limited political support. A lack of political will and resources can limit organisations in moving beyond discursive or symbolic action (Jacob et al., 2008). MAF was identified as a key linking organisation, however, the Ministry is tasked with multiple objectives across multiple sectors and has limited financial and technical resources. For MAF to enhance integration around one issue, such as fisheries, it will likely require transferring resources from other areas, potentially resulting in a loss of performance elsewhere (Candel and Biesbroek, 2016). When addressing the integration of fisheries and FNS, it will be essential to maintain resources for key fishery activities such as effective management. Integrated approaches can face financial and logistical barriers for large-scale initiatives, and may be easier to consider more integrated, multiple livelihood strategies for FNS interventions at the project level (Fisher et al., 2017). Engaging development partners, who currently have very limited inclusion of fish in their development strategies, through joint programming will be an important driver of future projects and resource allocation. 
564 Lack of political motivation has also been linked to the low priority for food and nutrition

565 globally (Cheng et al., 2014) and a lack of cohesion within the food and nutrition policy

566 community is recognised as a challenge in the food and nutrition sector (Heaver, 2005; Menon

567 and Stoltzfus, 2012; Natalicchio et al., 2009). Timor-Leste has a generally high level of

568 expressed commitment to food and nutrition, however, it performs poorly on 'institutional'

569 and 'budgetary' commitments, including the adoption of laws and policies supportive of

570 formulating and implementing the food and nutrition agenda, and adequate resource

571 allocations to accomplish programmatic initiatives (Cheng et al., 2014).

572

In many countries, including Sierra Leone and Timor Leste, the development of the fisheries

sector, and its contribution to FNS, is challenged by the effects of past conflict and the success

of post-conflict governance and interventions (Khan and Sei, 2015; López-Angarita et al.,

2019). Civil conflict can negatively affect fishery economic development over a long time

frame, through reduced fish catch, redeployment of fishers into other sectors and the

potential increase in illegal, unreported and unregulated fishing as a result of ineffective

management (Hendrix and Glaser, 2011). In Timor-Leste, the fisheries sector has been

negatively affected through the creation of a personnel void in fisheries administration (ADB,

2001), as well as through the destruction of fishing infrastructure during the Indonesian

withdrawal. Timorese staff were intentionally kept out of senior management positions in the

Indonesian public servants fled Timor-Leste, creating a vacuum in the public service, with a 
external human and financial resources, which has been shown to shape policy and practice according to international expectations in other post-conflict situations (Poole et al., 2018). While these governance issues are important in respect to the integration of fish and food, they are also relevant to the integration of food and nutrition security in national policy and to development challenges more broadly.

\subsection{Opportunities for improving policy integration}

Ideally, FNS programs and all development programs would be designed in a way that facilitated policy integration, or at least reduced conflicts (Candel and Biesbroek, 2016). Where the integration of fisheries and FNS may not be fully realisable, due to lack of support or lack of defined targets for example, the coordination of programs becomes critically important (Peters, 2018). Strategies to integrated fisheries and nutrition to improve health need to be layered and iterative over time or risk having limited impact. For example, efforts to integrate nutrition concerns into water, sanitation and hygiene interventions has had no effect on childhood stunting (Cumming et al., 2019). While the ambition to fully integrate fisheries and food policy nationally and internationally helps to envisage the desired future direction, in the face of challenges, a short-term approach may be to take the most immediate options to ensure that actions continue along the preferred path (Candel and Biesbroek, 2018), and to ensure more inclusive governance which actively engages fishers in decisionmaking processes (HLPE, 2014), in particular small-scale fishers and farmers.

Specific action for Timor-Leste to both improve integration of fisheries and aquaculture across sectors and contribute to improving FNS, include building on existing policy networks and working groups to: 
- Strengthen connections across shared objectives that are actively supported by key linking organisations and instruments. For example capacity building, sustainable production, increased production, poverty alleviation and food safety and quality. Plan 2011-2030 was identified as a key bridging document between sectors. This plan is aligned with the SDGs and also contains planned actions to enhance the performance of the fisheries and aquaculture sectors. The National Nutritional Strategy 2014-2019 was also identified, however, it lacks fishery and aquaculture systems, with minimal need for additional time and resources.

In the longer-term, coordination of programs across under-represented themes will also help overcome the trend for programmatic interventions that address FNS to take a single-sectoral approach (Fisher et al., 2017). We discuss some of these less integrated themes in more detail. 
Timor-Leste differs to other developing island nations, such as those in the Pacific, in that consumption of fish is low and food policy integration needs to also consider increasing consumption. Instruments including objectives to increase consumption typically also included detailed targets, however, they did not discuss how consumption will be increased and targets met. One exception is the National Aquaculture Development Strategy 2012-2030 that identifies the Ministry of Agriculture and Fisheries, the Ministry of Education, as well as the private sector, farmers and I/NGOs as key partners in actions to increase fish consumption. Several key documents with a specific focus on fisheries and food security did not include any objectives relating to increased consumption, or to nutritional intake. This finding extends to regional documents, such as the CTI, which lacks targets for improving access or consumption of fish (Foale et al., 2013). Increasing consumption may be less important for countries that already have high consumption, however, it is crucial for countries such as Timor-Leste where only small amount of fish and other animal protein are consumed (Wong et al., 2018). Promoting fish consumption may also be required in countries where a transition away from traditional foods, such as fish, toward 'modern' diets is resulting in higher rates of non-communicable diseases and food insecurity (Charlton et al., 2016).

Related objectives that would form important pathways for increasing consumption, for example, those relating to education and awareness, improving nutrition behaviour and food affordability were generally absent in fisheries policies and limited within food policy generally. Food price volatility is closely connected to the concept of FNS (FAO et al., 2015) and an understanding of the causes of volatility is important in order to implement appropriate policy responses (Kalkuhl et al., 2016), particularly in regions with higher fish 
price volatility (Tveteras et al., 2012). High prices were identified in consumption surveys as main reasons for not eating fish in Timor-Leste (López-Angarita et al., 2019).

Several interviewees noted activities in relation to improving nutrition behaviour and practices that linked to fish consumption, even if they were not directly involved. For example, the distribution of information on fish through comics and school magazines. Including fish consumption in education around food and nutrition is an important step toward integrating fish and food. Developing a better understanding of the nutrient composition of fish, and varied nutrient yields among fisheries, is required in all countries to facilitate the policy shifts needed to realise the potential of fish for FNS (Hicks et al., 2019; Thilsted et al., 2016).

Taboos around eating fish exist in many countries, including Timor-Leste (Fidalgo Castro, 2013). A reported social norm hindering increased fish consumption is that women need specific approval from men and children in order to cook and serve fish-based meals (Nugroho, 2017). Fish is also an expensive foodstuff that is not part of the ritual exchange system, unlike meat which is tightly linked to rituals and is valued beyond its consumption or exchange value (Alonso Población, 2013). The less important customary role of fish may represent a potential opportunity, as fish may be consumed directly unlike other animal proteins. Given the potential influence of taboos, interventions to increase fish consumption should recognise cultural importance, ritual exchange systems and patterns of consumption, as both the market economy and non-market exchanges influence the current development status of the country's fishery sector (Alonso Población, 2013). This is an important area to develop, particularly given that objectives relating to cultural and traditional values were 
680

681

682

683

684

685

686

687

688

689

690

691

692

693

694

695

696

697

698

699

700

701

702

lacking across all sectors and organisations, and that it is easier to change policy instruments than to change policy paradigms or core belief systems (Candel and Biesbroek, 2016). Cultural objectives must be incorporated into policy and practice, in particular as a means of providing practical examples to people in order to overcome barriers to fish consumption. For example, supporting women from coastal areas with young children to visit pregnant women living inland to share their experience and reinforce that eating fish will not negatively affect the baby.

\subsubsection{Supporting the role of women in fisheries}

Supporting the role of women in fisheries is an opportunity to link fisheries with FNS outcomes, given the links between improved gender equality in fisheries and to poverty reduction and development (Harper et al., 2013), as well as to improved FNS more broadly (Quisumbing et al., 1996). Our finding that objectives to support women were not well integrated into fishery policies reflects the global situation in which the role of women in fisheries and their contribution to food security has typically been overlooked in food policy (Harper et al., 2013). Women play an important role in the fisheries sector in Timor-Leste, in particular through gleaning and fish processing (Tilley et al., in review). The main role of women in the sector is predominantly to provide food for the family. This role is recognised through the recently developed National Fisheries Strategy 2018, although there are no strategic actions relating to support for women or for gender more broadly. Involving more women in decision making at every level, from national to community, across all countries, is an important aspect of the integration of fisheries in food policy. The Maubisse Declaration 
2018 is a positive step toward improved integration and cross-sectoral engagement on improving the lives of women in Timor-Leste.

\subsubsection{Increasing production}

Globally, fisheries policy tends to focus on maximising profit or yield (Stephenson et al., 2017). While increasing production is a common theme of fisheries policy in Timor-Leste, increased availability does not automatically lead to improved FNS (Allison, 2011; Bogard et al., 2017).

Refocussing fisheries policy towards more efficient and equitable distribution, and towards improving eating patterns to meet local nutritional needs, is required (Alonso Población, 2013) to overcome both geographic and socio-economic barriers. This finding is applicable to fisheries and food policy more broadly, given the links between access to fish and fisheries and FNS (Béné et al., 2016). Increased production also needs to be undertaken within biological limits. Sustainable production was a common objective theme within fishery organisations and instruments, however, it was less integrated within the FNS policy network.

\subsubsection{Value addition and market access}

The fisheries value chain has been identified as a means to improve the contribution of fish to FNS, in regions of both high and low fish consumption, by improving access, reducing loss and waste, and creating employment (HLPE, 2014). Fish-based value chains were identified as high potential areas for development in the Ministry of Agriculture and Fisheries Strategic Plan 2014-2020, and improving value chains was identified as a strategic action to improve FNS in the National Fisheries Strategy 2018. However, very little has reportedly been completed or planned to develop market infrastructure, reduce post-harvest loss or 
encourage and support private sector investment (Ministry of Agriculture and Fisheries, 2013).

Value chain improvement is hindered by the prior destruction of an estimated $70 \%$ of physical infrastructure by Indonesian militia during the conflict in Timor-Leste (World Bank, 2002). Loss

of infrastructure required for food production and distribution reduces resilience and increases vulnerability to food insecurity (Westlund et al., 2007). Damage to fishing infrastructure, in particular, can lead to substantial losses across supply chains and prevent sector development. The Hera Port ice machine, as well as a number of main public markets and fish landing sites, for example, were destroyed in Timor-Leste (Barbosa and Booth, 2009).

Similarly in Yemen, damages from conflict affected all aspects of the fishing sector, including infrastructure and fishing operations, as well as all stakeholders involved in fish processing and marketing (Al-Fareh, 2018).

Objectives relating to 'reduce food loss and waste', 'value addition and market access' and 'industry innovation/sector development', which require improved infrastructure, were lacking across sectors in instruments and interviews, particularly the food, nutrition and health sector. Several instruments across sectors had objectives relating to food safety and quality, however, this objective was not reported by any interviewees, despite some reported concern over fish quality from the use of formaldehyde.

Food insecurity in Timor-Leste is partly the result of low levels of food production combined with high food losses, both pre- and post-harvest (Borges et al., 2009). A lack of road side 
of an ice distribution system, combined with food safety promotion, should be considered as part of intervention into the fishery sector (Alonso Población, 2013). Engagement of both the government as a regulator of law and the private sector as an implementation agent will be important for improving value chains for fish, and other foods, and for developing new markets. Consideration will also need to be given to market integration, which has been highlighted as an issue when attempting to harmonise fisheries and aquaculture policies with FNS concerns (FAO, 2017).

Food security is well-integrated into fisheries policy Timor-Leste, but there is little evidence of the reciprocal integration of fish into food policy. A range of shared objective themes were identified between sectors and building on these will be a key step toward reconciling the competing demands of different policy instruments and achieving policy integration. Scope exists to improve the range of objectives themes covered. For example despite good integration of food within fisheries polices, a number of key FNS concerns were not well addressed. Integrating a broad range of objectives is important for supporting the role of fish in FNS, in particular those relating to the role of women, developing value chains, and increasing production and consumption. Policy network analysis revealed evidence of collaboration and cooperation between sectors, however, fish and food concerns are not well embedded across all organisations. Increased political will and resources, combined with clearer targets and actions within key instruments in particular, will help to better integrate fish and food policy and ultimately improve food and nutrition security. 
ADB, 2001. Report on a project grant from the Trust Fund for East Timor to East Timor for the Hera

Port Fisheries Facilities Rehabilitation Project, Report number 8190-TF-ETM ed. Asian Development Bank.

Al-Fareh, A.M., 2018. The impact of the war in Yemen on artisanal fishing of the Red Sea. , LSE Middle East Centre Report. LSE Middle East Centre, London, UK.

Allison, E.H., 2011. Aquaculture, Fisheries, Poverty and Food Security. Working Paper 2011-65. The WorldFish Center. Penang, Malaysia.

Alonso-Población, E., Rodrigues, P., Wilson, C., Pereira, M., Lee, R.U., 2018. Narrative assemblages for power-balanced coastal and marine governance. Tara Bandu as a tool for community-based fisheries co-management in Timor-Leste. Maritime Studies 17, 55-67.

Alonso Población, E., 2013. Fisheries and food security in Timor-Leste: the effects of ritual meat exchanges and market chains on fishing. Food Security 5, 807-816.

AMSAT International, 2011. Fish and animal protein consumption and availability in Timor-Leste. Regional Fisheries Livelihoods Programme for South and Southeast Asia (GCP/RAS/237/SPA) Anderson, T., 2006. Food Security and Agriculture in the Australia-East Timor Relationship, in: Leach, D.K.a.M. (Ed.), East Timor: Beyond Independence. Monash Asia Institute Press, Melbourne. Barbosa, M., Booth, S., 2009. East Timor's fisheries catch reconstruction (1950-2009): Fisheries under different regimes, in: Zeller, D.a.H., S. (Ed.), Fisheries catch reconstructions: Islands, Part I., Fisheries Centre, University of British Columbia, pp. pp. 39-51. In: .

Barling, D., Lang, T., Caraher, M., 2002. Joined-up Food Policy? The Trials of Governance, Public Policy and the Food System. Social Policy \& Administration 36, 556-574.

Béné, C., Arthur, R., Norbury, H., Allison, E.H., Beveridge, M., Bush, S., Campling, L., Leschen, W., Little, D., Squires, D., 2016. Contribution of fisheries and aquaculture to food security and poverty reduction: assessing the current evidence. World Development 79, 177-196.

Béné, C., Barange, M., Subasinghe, R., Pinstrup-Andersen, P., Merino, G., Hemre, G.-I., Williams, M., 2015. Feeding 9 billion by 2050 - Putting fish back on the menu. Food Security 7, 1-14.

Bennett, A., Patil, P., Kleisner, K., Rader, D., JohnVirdin, J., Basurto, X., 2018. Contribution of Fisheries to Food and Nutrition Security: Current Knowledge, Policy, and Research, in: NI Report 18-02. Durham, N.D.U. (Ed.).

Bhutta, Z.A., Das, J.K., Rizvi, A., Gaffey, M.F., Walker, N., Horton, S., Webb, P., Lartey, A., Black, R.E., 2013. Evidence-based interventions for improvement of maternal and child nutrition: what can be done and at what cost? The lancet 382, 452-477.

Bogard, J.R., Farmery, A., Little, D., Fulton, E.A., Cook, M., 2019. Will fish be part of future healthy and sustainable diets? The Lancet Planetary Health 3, e159-e160.

Bogard, J.R., Farook, S., Marks, G.C., Waid, J., Belton, B., Ali, M., Toufique, K., Mamun, A., Thilsted, S.H., 2017. Higher fish but lower micronutrient intakes: Temporal changes in fish consumption from capture fisheries and aquaculture in Bangladesh. PLOS ONE 12, e0175098.

Borges, L.F., do Rosario Ferreira, A., Da Silva, D., Williams, R., Andersen, R., Dalley, A., Monaghan, B., Nesbitt, H., Erskine, W., 2009. Improving food security through agricultural research and development in Timor-Leste: a country emerging from conflict. Food Security 1, 403.

Cabral, R.B., Halpern, B.S., Lester, S.E., White, C., Gaines, S.D., Costello, C., 2019. Designing MPAs for food security in open-access fisheries. Scientific Reports 9, 8033.

Candel, J.J., 2018. Diagnosing integrated food security strategies. NJAS-Wageningen Journal of Life Sciences 84, 103-113.

Candel, J.J.L., Biesbroek, R., 2016. Toward a processual understanding of policy integration. Policy Sciences 49, 211-231.

Candel, J.J.L., Biesbroek, R., 2018. Policy integration in the EU governance of global food security. Food Security 10, 195-209.

Candel, J.J.L., Pereira, L., 2017. Towards integrated food policy: Main challenges and steps ahead. Environmental Science \& Policy 73, 89-92. 
Chan, C.Y., Tran, N., Pethiyagoda, S., Crissman, C.C., Sulser, T.B., Phillips, M.J., 2019. Prospects and challenges of fish for food security in Africa. Global Food Security 20, 17-25.

Charlton, K.E., Russell, J., Gorman, E., Hanich, Q., Delisle, A., Campbell, B., Bell, J., 2016. Fish, food security and health in Pacific Island countries and territories: a systematic literature review. BMC public health 16, 285.

Cheng, C., Reich, M.R., Balarajan, Y., Fox, A.M., 2014. Measuring political commitment and opportunities to advance food and nutrition security: piloting a rapid assessment tool. Health Policy and Planning 30, 566-578.

Cohen, P.J., Song, A.M., Morrison, T.H., 2017. Policy Coherence with the Small-Scale Fisheries Guidelines: Analysing Across Scales of Governance in Pacific Small-Scale Fisheries, The Small-Scale Fisheries Guidelines. Springer, pp. 57-77.

Coral Triangle Initiative, 2009. Regional plan of action: Coral Triangle Initiative on coral reefs, fisheries and food security. Coral Triangle Initiative on Coral Reefs, Fisheries, and Food Security, Jakarta, Indonesia.[online] URL: http://www. coraltriangleinitiative.

org/sites/default/files/resources/CTI\% 20Regional\% 20Plan\% 20of\% 20Action_June 2023, 202009. Cumming, O., Arnold, B.F., Ban, R., Clasen, T., Mills, J.E., Freeman, M.C., Gordon, B., Guiteras, R., Howard, G., Hunter, P.R., 2019. The implications of three major new trials for the effect of water, sanitation and hygiene on childhood diarrhea and stunting: a consensus statement. BMC medicine 17, 1-9.

Democratic Republic of Timor-Leste, 2015. Timor-Leste Food and Nutrition Survey, Ministry of Health. Final Report 2013, Dili.

FAO, 2015. Voluntary Guidelines for Securing Sustainable Small-Scale Fisheries in the Context of Food Security and Poverty Eradication. Food and Agriculture Organization of the United Nations, Rome.

FAO, 2017. Strengthening sector policies for better food security and nutrition results. Policy guidance note. FAO.

FAO, 2018. The State of World Fisheries and Aquaculture 2018 - Meeting the sustainable development goals. Food and Agriculture Organization of the United Nations, Rome.

FAO, 2019. Fishery and Aquaculture Country Profiles: The Democratic Republic of Timor-Leste, in: Food and Agriculture Organization of the United Nations, F.a.A.D. (Ed.).

FAO, IFAD, WFP, 2015. The State of Food Insecurity in the World 2015. Meeting the 2015 international hunger targets: taking stock of uneven progress. Rome, FAO.

FAO/WHO, 2014. Rome Declaration on Nutrition: outcome document, Second International Conference on Nutrition. Food and Agriculture Organization, Rome.

Farmery, A.K., Gardner, C., Jennings, S., Green, B.S., Watson, R.A., 2017. Assessing the inclusion of seafood in the sustainable diet literature. Fish and Fisheries 18, 607-618.

Fidalgo Castro, A., 2013. An approach to the food habits of three communities in Timor-Leste. Final report for Care International in Timor-Leste.

Fisher, B., Naidoo, R., Guernier, J., Johnson, K., Mullins, D., Robinson, D., Allison, E.H., 2017. Integrating fisheries and agricultural programs for food security. Agriculture \& Food Security 6, 1. Foale, S., Adhuri, D., Aliño, P., Allison, E.H., Andrew, N., Cohen, P., Evans, L., Fabinyi, M., Fidelman, P., Gregory, C., Stacey, N., Tanzer, J., Weeratunge, N., 2013. Food security and the Coral Triangle Initiative. Marine Policy 38, 174-183.

Freeman, L., 2004. The development of social network analysis: A Study in the Sociology of Science. Empirical Press, Vancouver, BC Canada.

Golden, C., Allison, E.H., Cheung, W.W., Dey, M.M., Halpern, B.S., McCauley, D.J., Smith, M., Vaitla, B., Zeller, D., Myers, S.S., 2016. Fall in fish catch threatens human health. Nature 534, 317-320. Government of Timor Leste, 2015. Food-based dietary guidelines: Recommendations for Healthy Eating in TImor Leste, in: Ministry of Health, N.D.o.P.H., Department of Nutrition (Ed.), Dili, TimorLeste. 
Hall, S.J., Hilborn, R., Andrew, N.L., Allison, E.H., 2013. Innovations in capture fisheries are an imperative for nutrition security in the developing world. Proceedings of the National Academy of Sciences 110, 8393-8398.

878 Harper, S., Zeller, D., Hauzer, M., Pauly, D., Sumaila, U.R., 2013. Women and fisheries: Contribution to food security and local economies. Marine Policy 39, 56-63.

Heaver, R., 2005. Strengthening country commitment to human development: lessons from nutrition. The World Bank.

Hendrix, C.S., Glaser, S.M., 2011. Civil conflict and world fisheries, 1952-2004. Journal of peace research 48, 481-495.

Hicks, C.C., Cohen, P.J., Graham, N.A., Nash, K.L., Allison, E.H., D'Lima, C., Mills, D.J., Roscher, M., Thilsted, S.H., Thorne-Lyman, A.L., 2019. Harnessing global fisheries to tackle micronutrient deficiencies. Nature, 1-4.

HLPE, 2014. Sustainable fisheries and aquaculture for food security and nutrition, A report by the High Level Panel of Experts on Food Security and Nutrition of the Committee on World Food Security, Rome 2014.

Jacob, K., Volkery, A., Lenschow, A., 2008. Instruments for environmental policy integration in 30 OECD countries. Innovation in environmental policy? Integrating the environment for sustainability, 24-47.

Jarosz, L., 2011. Defining world hunger: scale and neoliberal ideology in international food security policy discourse. Food, culture \& society 14, 117-139.

Kalkuhl, M., von Braun, J., Torero, M., 2016. Volatile and extreme food prices, food security, and policy: an overview, Food Price Volatility and Its Implications for Food Security and Policy. Springer, Cham, pp. 3-31.

Kawarazuka, N., Béné, C., 2011. The potential role of small fish species in improving micronutrient deficiencies in developing countries: building evidence. Public Health Nutrition 14, 1927-1938. Khan, A., Sei, S., 2015. The Co-governance of Fisheries in Post-conflict Sierra Leone: Is the Transition for Better or for Worse?, Interactive Governance for Small-Scale Fisheries. Springer, pp. 559-581. Kickert, W.J., Klijn, E.-H., Koppenjan, J.F., 1997. Managing complex networks: Strategies for the public sector. Sage.

Kurien, J., López Ríos, J., 2013. Flavouring fish into food security, Report/Rapport: SF-FAO/2013/14. August/Aout 2013. FAO-SmartFish Programme of the Indian Ocean Commission, Ebene, Mauritius. López-Angarita, J., Hunnam, K., Pereira, M., Mills, D., Pant, J., Teoh, S., Eriksson, H., Amaral, L., Tilley, A., 2019. Fisheries and aquaculture of Timor-Leste in 2019: Current knowledge and opportunities. Loring, P.A., Fazzino, D.V., Agapito, M., Chuenpagdee, R., Gannon, G., Isaacs, M., 2019. Fish and Food Security in Small-Scale Fisheries, Transdisciplinarity for Small-Scale Fisheries Governance. Springer, pp. 55-73.

McClanahan, T., Allison, E.H., Cinner, J.E., 2013. Managing fisheries for human and food security. Fish and Fisheries 16, 78-103.

Meijers, E., Stead, D., 2004. Policy integration: what does it mean and how can it be achieved? A multi-disciplinary review, Berlin Conference on the Human Dimensions of Global Environmental Change: Greening of Policies-Interlinkages and Policy Integration. Berlin.

Menon, P., Stoltzfus, R.J., 2012. Building convergence in science, programs, and policy actions on child undernutrition: symposium rationale and overview. Advances in Nutrition 3, 224-226.

Mickwitz, P., Kivimaa, P., 2007. Evaluating policy integration: The case of policies for environmentally friendlier technological innovations. Evaluation 13, 68-86.

Mills, D.J., Tilley, A., Pereira, M., Hellebrandt, D., Pereira Fernandes, A., Cohen, P.J., 2017. Livelihood diversity and dynamism in Timor-Leste; insights for coastal resource governance and livelihood development. Marine Policy 82, 206-215.

Ministry of Agriculture and Fisheries, 2013. Agriculture Sector Development Medium Term Investment Plan (2014 - 2018). NATIONAL DIRECTORATE OF POLICY AND PLANNING, Dili. 
Miyazawa, N., 2013. Customary law and community-based natural resource management in postconflict Timor-Leste, in: Williams, J.U.a.R.C. (Ed.), Land and post-conflict peacebuilding. Earthscan, London.

Natalicchio, M., Garrett, J., Mulder-Sibanda, M., Ndegwa, S., Voorbraak, D., 2009. Carrots and sticks: the political economy of nutrition policy reforms, Health, Nutrition and Population (HNP) discussion paper. World Bank, Washington, DC.

Needham, S., Funge-Smith, S., 2014. The consumption of fish and fish products in the Asia-Pacific region based on household surveys. FAO Regional Office for Asia and the Pacific, Bangkok.

Nilsson, M., Zamparutti, T., Petersen, J.E., Nykvist, B., Rudberg, P., McGuinn, J., 2012. Understanding policy coherence: analytical framework and examples of sector-environment policy interactions in the EU. Environmental Policy and Governance 22, 395-423.

Nohrstedt, D., Weible, C.M., 2010. The Logic of Policy Change after Crisis: Proximity and Subsystem Interaction. Risk, Hazards \& Crisis in Public Policy 1, 1-32.

Nugroho, W., 2017. Identifying Behaviors to Improve Fish Consumption in Timor-Leste, Agrilinks. Peters, B.G., 2018. The challenge of policy coordination. Policy Design and Practice 1, 1-11. Poole, N., Echavez, C., Rowland, D., 2018. Are agriculture and nutrition policies and practice coherent? Stakeholder evidence from Afghanistan. Food Security 10, 1577-1601.

Provo, A., Atwood, S., Sullivan, E., Mbuya, N., 2016. Malnutrition in Timor-Leste: A review of the burden, drivers, and potential response. World Bank. Working Paper.

Quirk, G., Voyer, M., Farmery, A., Kajlich, L., Warner, R., in review. Policy coherence in the Blue Economy: the role of legislative and policy objectives. Marine Policy.

Quisumbing, A.R., Brown, L.R., Feldstein, H.S., Haddad, L., Peña, C., 1996. Women: The key to food security. Food and Nutrition Bulletin 17, 1-2.

Rosin, C., 2013. Food security and the justification of productivism in New Zealand. Journal of Rural Studies 29, 50-58.

Stephenson, R.L., Benson, A.J., Brooks, K., Charles, A., Degnbol, P., Dichmont, C.M., Kraan, M., Pascoe, S., Paul, S.D., Rindorf, A., Wiber, M., 2017. Practical steps toward integrating economic, social and institutional elements in fisheries policy and management. Ices Journal of Marine Science 74, 1981-1989.

Thilsted, S.H., Thorne-Lyman, A., Webb, P., Bogard, J.R., Subasinghe, R., Phillips, M.J., Allison, E.H., 2016. Sustaining healthy diets: The role of capture fisheries and aquaculture for improving nutrition in the post-2015 era. Food Policy, 126-131.

Tilley, A., Burgos, A., Duarte, A., dos Reis Lopes, J., Eriksson, H., Mills, D.J., in review. Women's contributions to food and income from small-scale fisheries in Timor-Leste. Ambio.

Tilley, A., Hunnam, K.J., Mills, D.J., Steenbergen, D.J., Govan, H., Alonso-Poblacion, E., Roscher, M., Pereira, M., Rodrigues, P., Amador, T., 2019. Evaluating the fit of co-management for small-scale fisheries governance in Timor-Leste. Frontiers in Marine Science 6, 392.

Tomlinson, I., 2013. Doubling food production to feed the 9 billion: a critical perspective on a key discourse of food security in the UK. Journal of rural studies 29, 81-90.

Tveteras, S., Asche, F., Bellemare, M.F., Smith, M.D., Guttormsen, A.G., Lem, A., Lien, K., Vannuccini, S., 2012. Fish Is Food - The FAO's Fish Price Index. PLoS ONE 7.

von Grebmer, K., Bernstein, J., Patterson, F., Sonntag, A., Klaus, L., Fahlbusch, J., Towey, O., Foley, C., Gitter, S., Ekstrom, K., Fritschel, H., 2018. Global Hunger Index. Welt Hunger Life, Concern Worldwide, Dublin / Bonn.

Wasserman, S., Faust, K., 1994. Social network analysis: Methods and applications. Cambridge university press, Cambridge, UK.

Westlund, L., Poulain, F., Bage, H., 2007. Disaster response and risk management in the fisheries sector, FAO Fisheries Technical Paper No. 479. Food and Agriculture Organization of the United Nations, Rome, Italy.

Wong, J.T., Bagnol, B., Grieve, H., da Costa Jong, J.B., Li, M., Alders, R.G., 2018. Factors influencing animal-source food consumption in Timor-Leste. Food Security 10, 741-762. 
976 World Bank, 2002. East Timor Policy Challenges for a New Nation: Country Economic Memorandum.

977 World Bank, Poverty Reduction and Economic Management Unit.

978 WorldFish, 2019. Timor-Leste.

979 